\title{
Campodeidae (Hexapoda: Diplura) from Kyrgyzstan, Central Asia, with the description of a remarkable new genus and species
}

\author{
Alberto SENDRA ${ }^{1, *}$, Alba SÁNCHEZ-GARCÍA ${ }^{2}$, Jesús SELFA $^{3}$, \\ Dmitry A. MILKO ${ }^{4} \&$ Rodrigo Lopes FERREIRA ${ }^{5}$ \\ ${ }^{1}$ Colecciones Entomológicas Torres-Sala; Servei de Patrimoni Històric, Ajuntament de València, \\ Passeig de la Petxina, 15, 46008 València, Spain. \\ ${ }^{1}$ Departament de Didàctica de les Ciències Experimentals i Socials, Facultat de Magisteri, Universitat \\ de València, Avda. Tarongers 4, 46022 València, Spain. \\ ${ }^{2}$ Departament de Botànica i Geologia, Facultat de Ciències Biològiques, Universitat de València, \\ C/ Dr. Moliner 50, 46100 Burjassot, València, Spain. \\ ${ }^{2}$ Division of Invertebrate Zoology, American Museum of Natural History, Central Park West at $79^{\text {th }}$ \\ Street, New York, NY 10024-5192, USA. \\ ${ }^{3}$ Laboratori d'Investigació d'Entomologia, Departament de Zoologia, Universitat de València, C/ Dr. \\ Moliner 50, 46100 Burjassot, València, Spain. \\ ${ }^{4}$ Kyrgyz National Academy of Sciences, Bishkek, Kyrgyzstan. \\ ${ }^{5}$ Centro de Estudos em Biologia Subterrânea, Departamento de Ecologia e Conservação, Universidade \\ Federal de Lavras, Lavras, MG, CEP 37200-900, Brazil. \\ *Corresponding author: alberto.sendra@uv.es \\ ${ }^{2}$ Email: alba.sanchez@uv.es \\ ${ }^{3}$ Email: jesus.selfa@uv.es \\ [4Email:dmmilko@yahoo.com \\ ${ }^{5}$ Email: drops@ufla.br

\footnotetext{
${ }^{1}$ urn:1sid:zoobank.org:author:11636BAE-AE66-4898-A7C8-35B329E7E3A8

${ }^{2}$ urn:lsid:zoobank.org:author:86DFDA66-BEC1-428A-A7B0-E90FCFFABCE3

${ }^{3}$ urn:lsid:zoobank.org:author:C01B4FA6-6C5C-4DDF-A114-2B06D8FE4D20

${ }^{5}$ urn:lsid:zoobank.org:author:DAADEEBA-4DE9-44B4-8FD0-A9EAF410420A
} \\ ${ }^{4}$ urn:lsid:zoobank.org:author:B2D9C408-CDF9-4184-BCD1-F09EAB049333
}

\begin{abstract}
Samples collected in Central Asia, Kyrgyzstan, have revealed a hitherto unknown diversity of Campodeidae (Diplura) in soil and cave habitats, including a new genus and species, Kyrgyzstancampa sanare Sendra \& Ferreira gen. et sp. nov., Turkmenocampa edaphica Sendra \& Sánchez-García sp. nov. and a previously recognized soil-dwelling species, Campodea (Dicampa) catalana Denis, 1930. Kyrgyzstancampa sanare Sendra \& Ferreira gen. et sp. nov. was collected in the deep zone of an interesting geological and cultural cave, Ak-Turpak Cave, located near the western margin of Kadamjay District, Batken Province. This genus belongs to the subfamily Campodeinae, sharing the morphology of the pretarsus with Eutrichocampa and other related genera, but differing from them in the shape of the claws and the laminar lateral processes, in addition to its unique cupuliform organ and the macrosetal pattern on the thorax and abdomen. Turkmenocampa edaphica Sendra \& Sánchez-García sp. nov. was
\end{abstract}


found in humid edaphic habitats, under stones or near roots, and is morphologically and geographically very similar to the cave-dwelling species Turkmenicampa mirabilis Sendra \& Stoev, 2017, which occurs in an isolated cave in the nearby country of Turkmenistan.

Key words. Asia, biogeography, caves, soil fauna.

Sendra A., Sánchez-García A., Selfa J., Milko D.A. \& Ferreira R.L. 2021. Campodeidae (Hexapoda: Diplura) from Kyrgyzstan, Central Asia, with the description of a remarkable new genus and species. European Journal of Taxonomy 782: 1-20. https://doi.org/10.5852/ejt.2021.782.1585

\section{Introduction}

Diplurans are one of three groups of entognathous hexapods present in almost every soil, cave, or any other empty subsurface space, and represented with 1009 species in 141 genera (Sendra et al. 2021). The order Diplura is divided into ten families, of which Campodeidae Meinert, 1865, with 491 species, accounts for nearly half (49\%) of the known species (Sendra et al. 2021). Despite their worldwide distribution, diplurans are virtually unknown in Central Asia. This vast geographical region covers an area of approximately 4 million square kilometres, stretching from the Caspian Sea (west) to the border of China (east), and from the southern borders of Russia (north) to the northern borders of Iran, Afghanistan, and China (south). Central Asia is politically composed of five independent countries, the former Soviet republics of Kazakhstan, Uzbekistan, Tajikistan, Kyrgyzstan, and Turkmenistan. Only one taxon of Campodeidae has been recorded from all of Central Asia, the recently described Turkmenocampa mirabilis Sendra \& Stoev, 2018 found in Kaptarhana Cave, an isolated habitat in Eastern Turkmenistan (Sendra et al. 2017). Two soil-dwelling species (Campodea (Dicampa) sprovierii Silvestri, 1932 and Campodea (Campodea) fragilis Meinert, 1865) have been described from the northern fringe of Iran (Azadbakhsh \& Nozari 2016).

In this paper, a new genus and two new species are described. The first records of Campodeidae from Kyrgyzstan are provided; diplurans of the family Japygidae Haliday, 1864 were also collected but have not yet been studied. The new records presented here come from sampling conducted during two expeditions in Kyrgyzstan. The first sampling effort, carried out 10-24 Jul. 2019, was targeted especially at cave and non-cave arthropod fauna, and was conducted by a Spanish team guided by Kyrgyzstan speleologists. The second effort, carried out by a team of Brazilian and Kyrgyzstan researchers, took place 5-16 Aug. 2019, and aimed to sample cave invertebrates in order to understand how communities respond to habitat traits.

\section{Material and methods}

\section{Study area}

Although Kyrgyzstan is a highly mountainous country (from the southern Chatkal Mountains to the northern slopes of the Altái Mountains), it has variable landscapes ranging from vast deserts to shrublands (Fig. 1). As a result, it has areas with warm continental and cold desert climates, and only in the soils of the mountain relief have samples of diplurans been found, probably due to the hot weather at the time the expedition took place. In relation to caves, the first aim of both expeditions, the karst outcrops of Kyrgyzstan, include few natural caves distributed over an extensive karst area, about $30 \%$ of the country. However, its speleological potential is still poorly explored, especially due to the difficulties in accessing caves in the high mountains. The karst areas of Kyrgyzstan are mainly associated with Carboniferous and Devonian limestones. 


\section{Sampling and imaging}

As previously mentioned, specimens from different species were found during two expeditions to Kyrgyzstan. In the first expedition, four caves and five external mountains areas were inventoried. Specimens were directly collected with a brush after sieving the soil samples and were stored in ethanol $(70-75 \%)$. In the second expedition, eight caves were sampled by active search in 10-m transects and quadrants $\left(1 \mathrm{~m}^{2}\right)$, prioritizing locations such as organic deposits (e.g., guano piles) and potential microhabitats (e.g., under stones, moist soil, cracks, speleothems). Opportunistic sampling was also carried out throughout the caves in search of other invertebrates. Specimens of the new genus were collected with a fine brush moistened in $70 \%$ ethanol and were immediately transferred to vials containing $70 \%$ ethanol. These were the only Campodeidae found during the second expedition.

In the laboratory, specimens were washed with distilled water, mounted on a slide with Marc André II solution, and examined under a phase-contrast optical microscope (Leica DMLS). The illustrations were made with a drawing tube and measurements were taken with an ocular micrometer. To determine body length, specimens were mounted in toto and measured from the base of the distal macrochaetae on the frontal process to the supra-anal abdominal valve. Four specimens were coated with palladium-gold for SEM photography (Hitachi S-4900) and sensilla measurement.

\section{Morphological study}

The morphological descriptions and abbreviations follow Condé (1955). We use the term gouge sensilla for the concave-convexly shaped sensilla on the antennae (Bareth \& Condé 1981).

\section{Abbreviations for morphological measurements}

For the position of macrosetae, we adopted the abbreviations of Condé (1955).

$l a=$ lateral-anterior

$l p=$ lateral-posterior

$m a=$ medial-anterior

post $=$ posterior

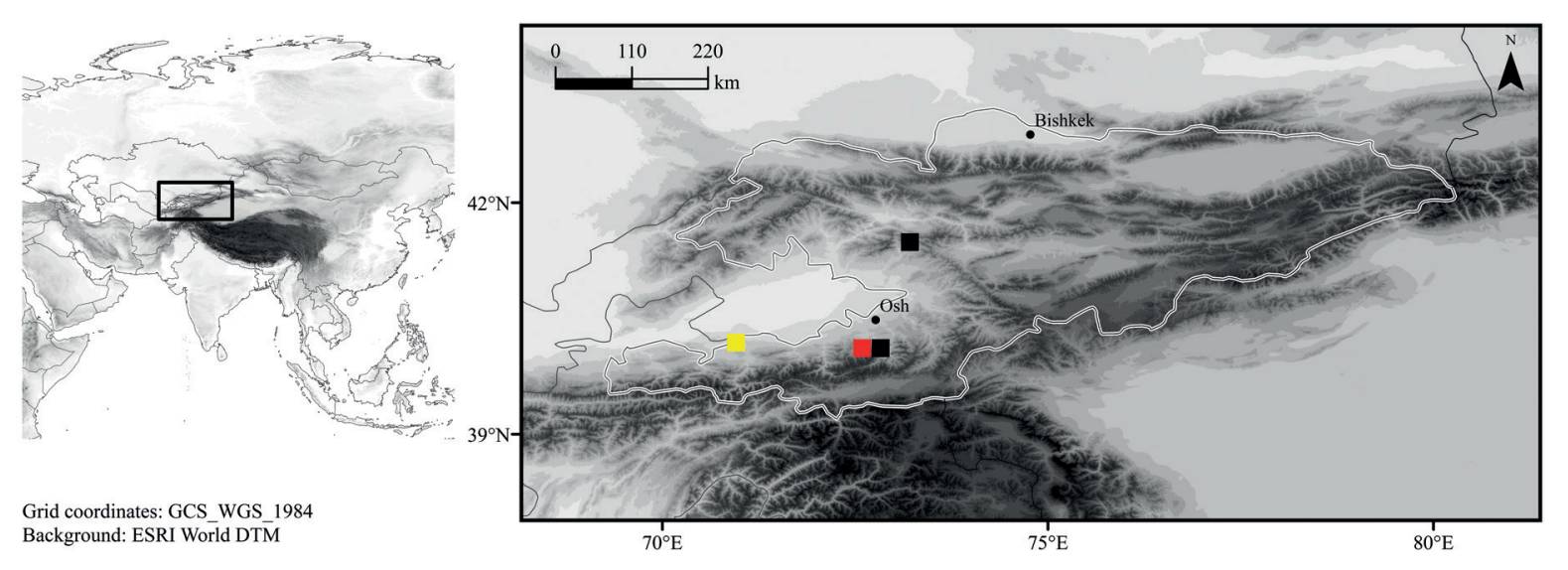

Fig. 1. Relief map of part of Asia with detail of Kyrgyzstan and adjacent regions with the localities at which diplurans were found; Kyrgyzstancampa sanare Sendra \& Ferreira gen. et sp. nov. (yellow square); Campodea (Dicampa) catalana Denis, 1930 (red square); Turkmenocampa edaphica Sendra \& Sánchez-García sp. nov. (black square). 


\title{
Institutional abbreviations
}

The holotype, paratypes, and other specimens studied are housed in the following institutions:

Coll. AS = private collection of Alberto Sendra, València, Spain

$\mathrm{IBB} \quad=$ Institute of Biology, Bishkek, Kyrgyzstan

ISLA = Coleção de Invertebrados Subterrâneos de Lavras, Lavras, Minas Gerais, Brazil

MZB = Museu de Ciències Naturals de Barcelona, Spain (MCNB)

\section{Results}

\author{
Class Diplura Börner, 1904 \\ Superfamily Campodeoidea Lubbock, 1873 \\ Family Campodeidae Meinert, 1865 \\ Subfamily Campodeinae Condé, 1956 \\ Genus Campodea Westwood, 1842 \\ Subgenus Dicampa Silvestri, 1932
}

Campodea (Dicampa) catalana Denis, 1930

Campodea (Dicampa) catalana Denis, 1930: 28, figs 7-13.

\section{Material examined}

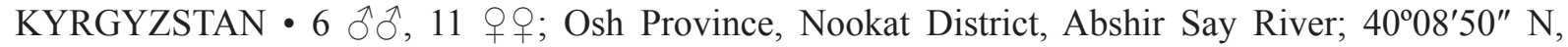
72²1'52" E; alt. 1851 m; 21 Jul. 2019; Alberto Sendra leg.; endogean habitat near Cupressus tree; Coll. AS.

\section{Remarks}

Campodea (Dicampa) catalana is an abundant species in Western Mediterranean soil habitats. This finding seems to show a disjunct distribution on both sides of the Mediterranean region.

Genus Kyrgyzstancampa Sendra \& Ferreira gen. nov.

urn:lsid:zoobank.org:act:8647AF6F-06B9-4D69-A01B-89BF113788C5

\section{Type species}

Kyrgyzstancampa sanare Sendra \& Ferreira gen. et sp. nov.

\section{Diagnosis}

Sensilla of cupuliform organ paddle-shaped. Notal macrosetae pattern with $3+3 m a$, $l a$, and $l p$ on pronotum and mesonotum. Femora with one dorsal macroseta and tibiae with one ventral macroseta. Claws subequal and regularly curved with ventral and lateral microspines. Laminar lateral processes striate on dorsal side with ridges surpassing apex and with short barbs on ventral side. Urotergites IVII with up to $1+1 l a$ and $2+2 l p$ macrosetae. First urosternite with $5+5$ macrosetae, second to seventh urosternites with $3+3$, and eighth urosternite with $1+1$ macrosetae. First urosternite in males with glandular $g_{1}, a_{2}$ and $a_{1}$ setae; first urosternite in females with glandular $a_{1}$ setae.

\section{Etymology}

The genus name is a combination of 'Kyrgyzstan', the country where the material was found, and 'campa', a commonly applied suffix to dipluran generic names. 
Kyrgyzstancampa sanare Sendra \& Ferreira gen. et sp. nov. urn:1sid:zoobank.org:act:012CDB29-579C-432F-B6C0-2DEE0F408BE5

Figs 8-26

\section{Etymology}

The specific epithet is taken from the Latin 'sanare', meaning 'cure' and is related to the cave where the species was found, which is used for therapeutic purposes. This should be treated as a noun in apposition.

\section{Type material}

Holotype

KYRGYZSTAN • + ; “holotype- + IBB 92101”; Ak-Turpak Cave; 40¹0'35.18" N, 71'03'45.36" E; alt. 900 m; 12 Aug. 2019; R.L. Ferreira leg.; IBB 92101.

\section{Paratypes}

KYRGYZSTAN • 1 q, mounted in Marc André II solution; "paratype- 901 MZB (MCNB) 2021-2338"; same collection data as for holotype; MZB (MCNB) 2021-2338 • 1 q, mounted in Marc André II solution; "paratype- 92 Coll. AS"; same collection data as for preceding; Coll. AS $\bullet 1 \hat{\jmath}$, mounted in

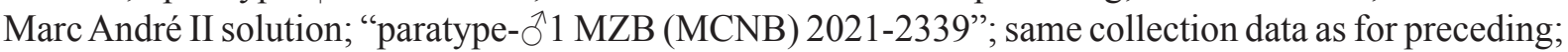

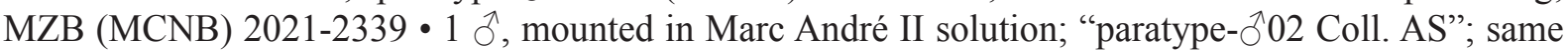
collection data as for preceding; Coll. AS.

\section{Other material}

Two specimens with the same data as the holotype were mounted on an aluminium stage and coated with palladium-gold.

\section{Description}

Body. Length 3-3.9 mm (3-3.9 $\mathrm{mm}$ in females; 3.1 and $3.4 \mathrm{~mm}$ in males; $3.9 \mathrm{~mm}$ in holotype) (Figs 8-9). Epicuticle smooth under optical microscope on dorsal side of nota and legs, but, at high magnification, slightly reticulate with irregular polygonal structures of variable size (Figs 16-17). Body sparsely covered with short clothing setae bearing $0-3$ tiny distal barbs.

HEAD. Two apparently intact antennae with $27-28$ antennomeres; antennae $0.28-0.29 \times$ length of body, with medial antennomeres $1.1 \times$ as long as wide; apical antennomere $1.9 \times$ as long as wide. Cupuliform organ with about eight plain paddle-shaped olfactory chemoreceptor sensilla, $7 \mu \mathrm{m}$ long (Fig. 10). Distal and medial antennomeres with two whorls of barbed macrosetae and scattered smooth setae, plus 2-4 short thin gouge sensilla 8-9 $\mu \mathrm{m}$ long (Figs 11-12). Proximal antennomeres with typical trichobothria, plus small bacilliform sensillum 6-7 $\mu \mathrm{m}$ long on $3^{\text {rd }}$ antennomere in ventral position (Figs 13-14). Plain frontal process with one anterior and three posterior smooth setae; length ratios of a/p 53/23 in holotype. Four short, smooth macrosetae along each side of antennomere insertion line with length ratios of $a / i 1$ and $i 2 / p 11 / 15 / 14 / 11$ in holotype; no $x$ setae observed (Fig. 15). Small subtrapezoidal labial palp with small subcylindrical latero-external sensillum; two guard setae, up to three simple setae on anterior border, and up to 35 neuroglandular setae, as well as short and coniform palpiform sensillum, in holotype.

Thorax. Thoracic macrosetae distribution (Figs 16-18): pronotum and mesonotum with 1+1 $m a, 1+1$ la $1+1$ lp macrosetae; metanotum with 1+1 ma macrosetae. All macrosetae rather slender with short barbs along middle third; marginal setae similar to clothing setae (Fig. 17). Legs short, metathoracic legs reaching abdominal segment $\mathrm{V}$, about $0.3 \times$ length of body (Fig. 19). Large, deep joint between femur and tibia with longitudinal protrusion on inner side (Fig. 20). Femora I-III each with one middle-sized 

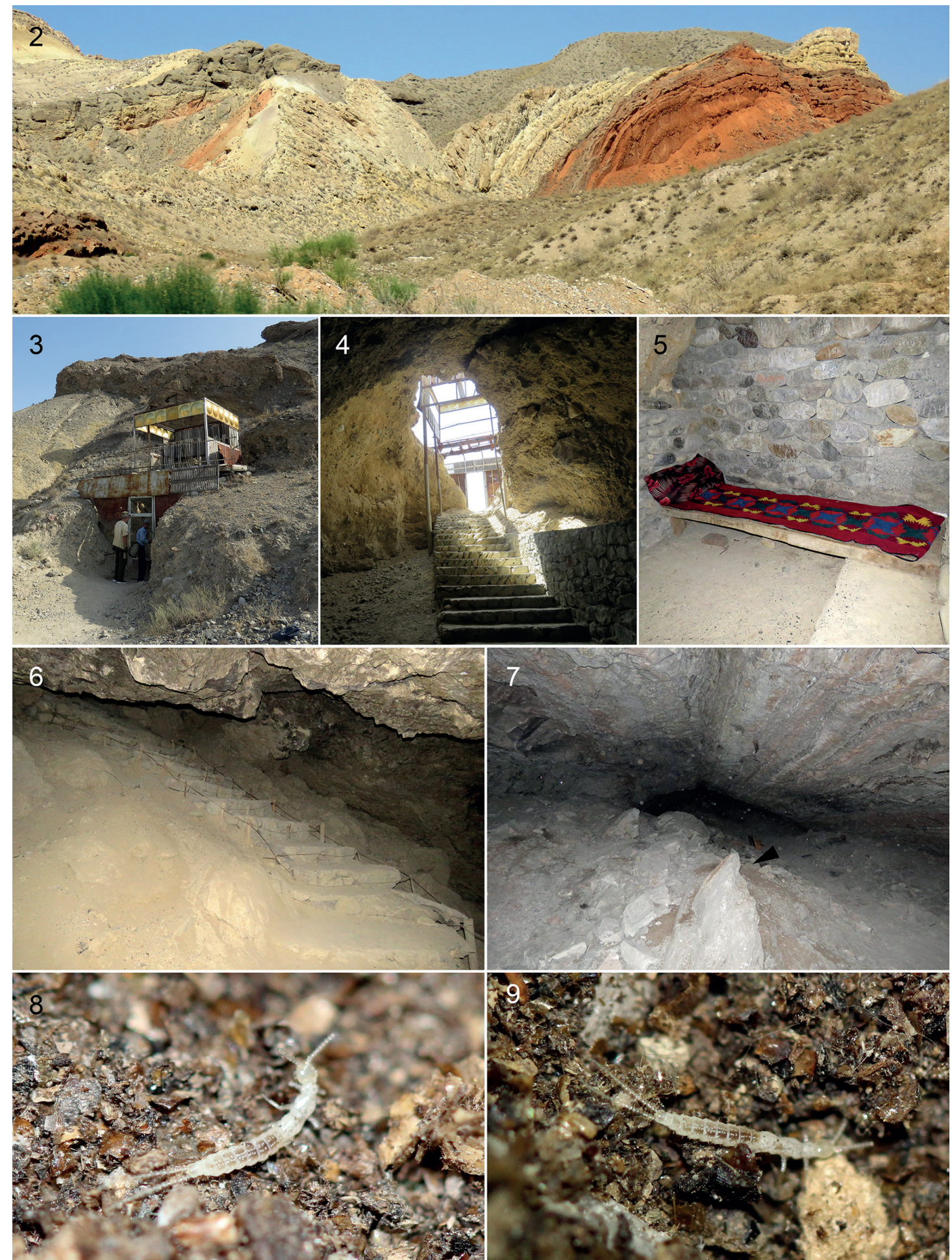

Figs 2-9. Ak-Turpak Cave, Kadamjay District, Batken Region in Kyrgyzstan in Central Asia. 2. Whitish, pinkish, or reddish clayey ground surface where the entrance is located. 3. Entrance of the cave, exterior view. 4. Entrance of the cave, interior view. 5. Small platforms and mattresses near the entrance. 6. Stairs installed deep inside the cave. 7. Last chamber of the cave, which is always associated with old bat guano. 8. Individual of Kyrgyzstancampa sanare Sendra \& Ferreira gen. et sp. nov., observed amidst guano. 9. Another specimen of $K$. sanare Sendra \& Ferreira gen. et sp. nov. 
dorsal macroseta with few distal barbs, slightly longer than ventral macroseta. Calcars slightly thickened with long barbs on one side. Tibiae I-III with one ventral macroseta with three or four distal barbs. Two rows of ventral barbed setae longer and thicker than clothing setae, with long thin barbs. Three smooth, distal dorsal tarsal setae longer than rest. Claws subequal, regularly curved, with tiny ventral and lateral microspines. Laminar lateral processes of pretarsus striated on dorsal side with ridges surpassing end of the apex, giving appearance of distal fringe, and with short barbs on ventral side (Figs 21-24).

AвDomen. Distribution of abdominal macrosetae on tergites: $1+1$ lp on urotergite III; $1+1 l a, 2+2 l p$ on urotergites IV-VIII; $3+3 l p$ on abdominal segment IX; $5+5$ macrosetae on abdominal segment X; all macrosetae long, with thin barbs along distal half. Urosternite I apparently with $5+5$ macrosetae (Figs 25-26); urosternites II-VII with 3+3 macrosetae; urosternite VIII with 1+1 macrosetae; longsized urosternal macrosetae with few distal barbs. Stylus with apical seta with two long basal teeth, subapical seta and ventromedial seta, each bearing a row of barbs along distal half, more abundant on ventromedial setae.

CERCI. $0.71 \times$ length of body (on a cercus apparently intact in the holotype), with basal article divided into four secondary articles plus 11 primary articles; each primary article with central constriction bearing whorl of long macrosetae with thin barbs on distal part and one or two whorls of thin smooth setae; each primary article ending in whorl of thin setae, including apical article.

SeCONDARY SeX Characters. Female urosternite I with short subcylindrical appendages, each bearing up to 11-13 glandular $a_{1}$ setae in distal field (Fig. 27). Male urosternite I with elongated subtrapezoidal appendages, each bearing up to 8 glandular $a_{1}$ setae in distal field and larger posterior field with up to 70 glandular $a_{2}$ setae; posterior edge of first urosternite with field of up to 44 glandular $g_{1}$ setae arranged in two rows (Fig. 25).

\section{Type locality}

Kyrgyzstan, Kadamjay District, Batken Region, Ak-Turpak Cave, gypsum cave located south of AkTurpak village; $40^{\circ} 10^{\prime} 35.18^{\prime \prime} \mathrm{N}, 71^{\circ} 03^{\prime} 45.36^{\prime \prime} \mathrm{E}$.

\section{Habitat}

The specimens were observed only in the deep zone of Ak-Turpak Cave, located near the western margin of the Kadamjay District, Batken Province, Kyrgyzstan, which is located about $2.5 \mathrm{~km}$ south of the village of Ak-Turpak (northwestern part of Alai Mts.). The name of the locality means 'white land' in the local Turkish dialect and reflects the prevalence of the whitish, pinkish, or reddish clayey ground surface. Its entrance is located about $400 \mathrm{~m}$ from the right bank of the river Sokh (Kozheshken) (Fig. 2), approximately 40-50 m a.s.l. The Sokh River divides the northern macroslopes of the Turkestan Mt Range and Alai (or Alay) Mt System. This area can also be considered as the southern edge of the Fergana Depression. The cave entrance is surrounded by a hilly relief, without any tops above $1000 \mathrm{~m}$ a.s.l. in a one-kilometre-neighbourhood. The landscape surrounding the Kyzyl-Unkuyr Cave is quite dry (Figs 2-3), with only sparse shrubby vegetation typical of rocky outcrops, where the soil is extremely shallow when present. On the other hand, the Sokh River floodplain, located quite close to the cave, is moist although it is currently very altered due to the presence of crops and small villages. However, suitable habitats for soil invertebrates certainly occur along this floodplain. It is worth mentioning that although Kyrgyzstancampa sanare Sendra \& Ferreira gen. et sp. nov. was found in a cave, it does not show any troglomorphic morphological characters. Thus, it is likely that the species is not troglobitic, although further sampling in the external area surrounding the cave (especially along the floodplain of the Sokh River) is needed to confirm this hypothesis. 

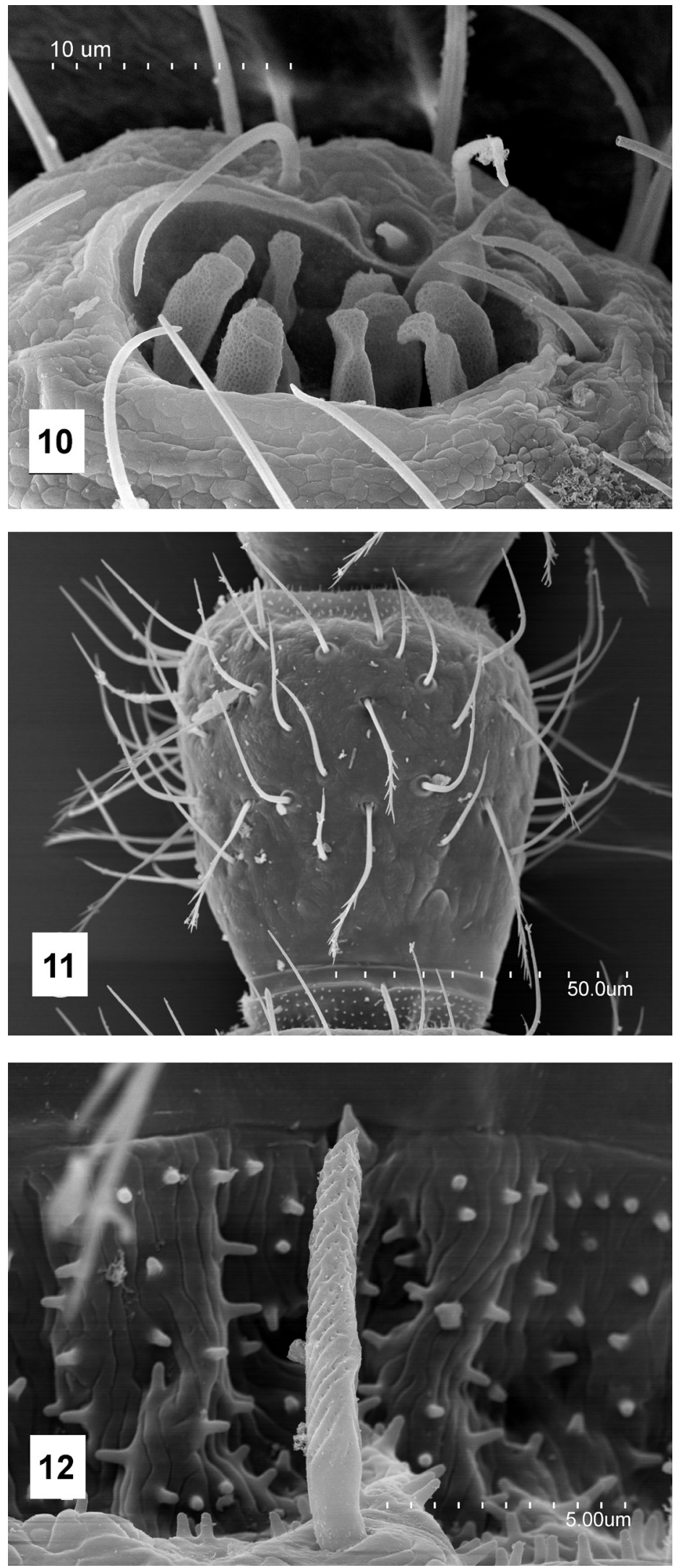

Figs 10-12. Kyrgyzstancampa sanare Sendra \& Ferreira gen. et sp. nov., §,, paratype (Coll. AS). 10. Cupuliform organ in the last antennomere. 11. Medial antennomere. 12. Gouge sensillum. 
The Ak-Turpak cave has a single entrance, where a metallic structure was installed to safeguard and protect the cave's entrance (Figs 3-4). From the entrance inwards, stairs were built to facilitate access for visitors. The cave gallery is comparatively simple and oriented east-northeast, with $137 \mathrm{~m}$ of linear extension and about 40 m deep (Gvozdetskij 1981; Dudashvili \& Mikhailyov 1990). The area of the cave was estimated to be $2400 \mathrm{~m}^{2}$ and the volume is $8393 \mathrm{~m}^{3}$ (Mamatkulov 1978). The cave is situated in a gypsum stratum (Gvozdetskij 1981) in the trough zone, where karstified rocks are represented by gypsum, marls, marlstones, limestones, and dolomites of Cretaceous and Paleogene ages (Beloglazova \& Smirnova 1987; Sultanov 1972). The origin of all karst forms in Southern Fergana is related to tectonic faults and sedimentary breccias, and they often developed as a result of repeated and sometimes overlapping karst processes (Sultanov 1972).

In the upper part of the cave conduit, there is a noticeable proportion of soft marl that is somewhat dilapidated (during the last 5-10 years, this part of the gallery was equipped with a cement staircase and the walls were partly reinforced with rubble masonry panels to reduce dust and for balneological and recreational use). In the deeper parts of the gallery, the cave vaults are formed by fine-crystalline selenite (calcium sulphate dihydrate $\mathrm{CaSO}_{4} \cdot 2 \mathrm{H}_{2} \mathrm{O}$ ) of several, sometimes contrasting, colour shades. The north side of the cave is preferentially formed by argillite. The atmosphere of the Ak-Turpak cave is rather dry and there are no traces of thermokarst processes (Dudashvili \& Mikhailyov 1990); however, the cave vaults are somewhat crumbled after recent earthquakes.

Over the last decades, local residents $(\approx 100-330$ per year) have used the cave for therapeutic purposes (respiratory treatments: asthma, bronchitis, etc.) as word of mouth on the cave's 'healing properties'
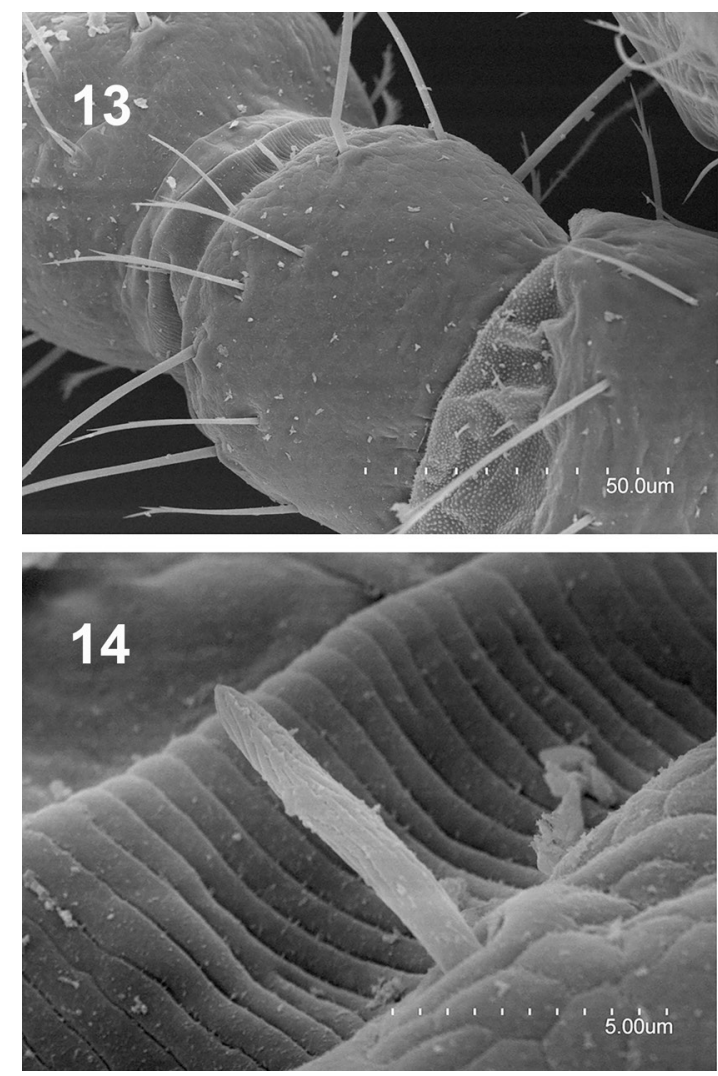

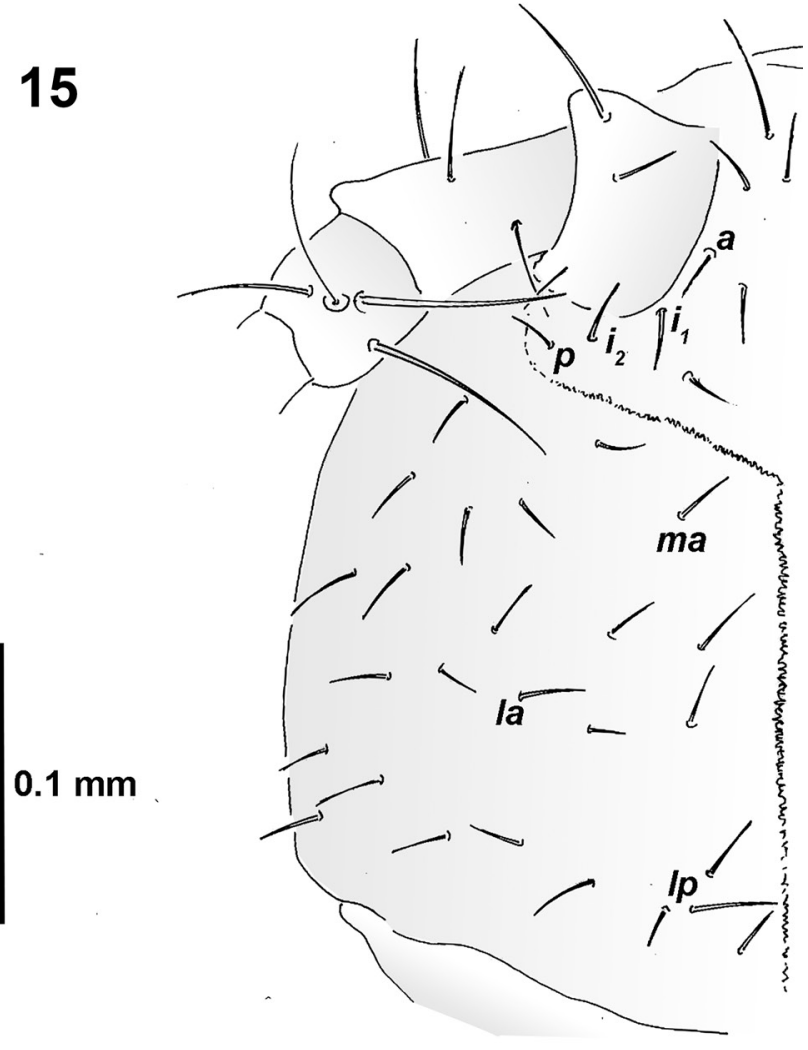

Figs 13-15. Kyrgyzstancampa sanare Sendra \& Ferreira gen. et sp. nov. 13. $\overbrace{}^{\lambda}$, paratype (Coll. AS), $3^{\text {rd }}$

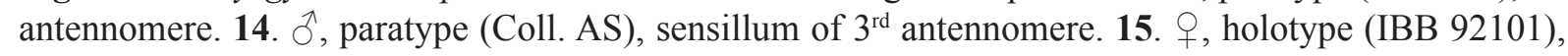
left portion of the head at dorsal view. 


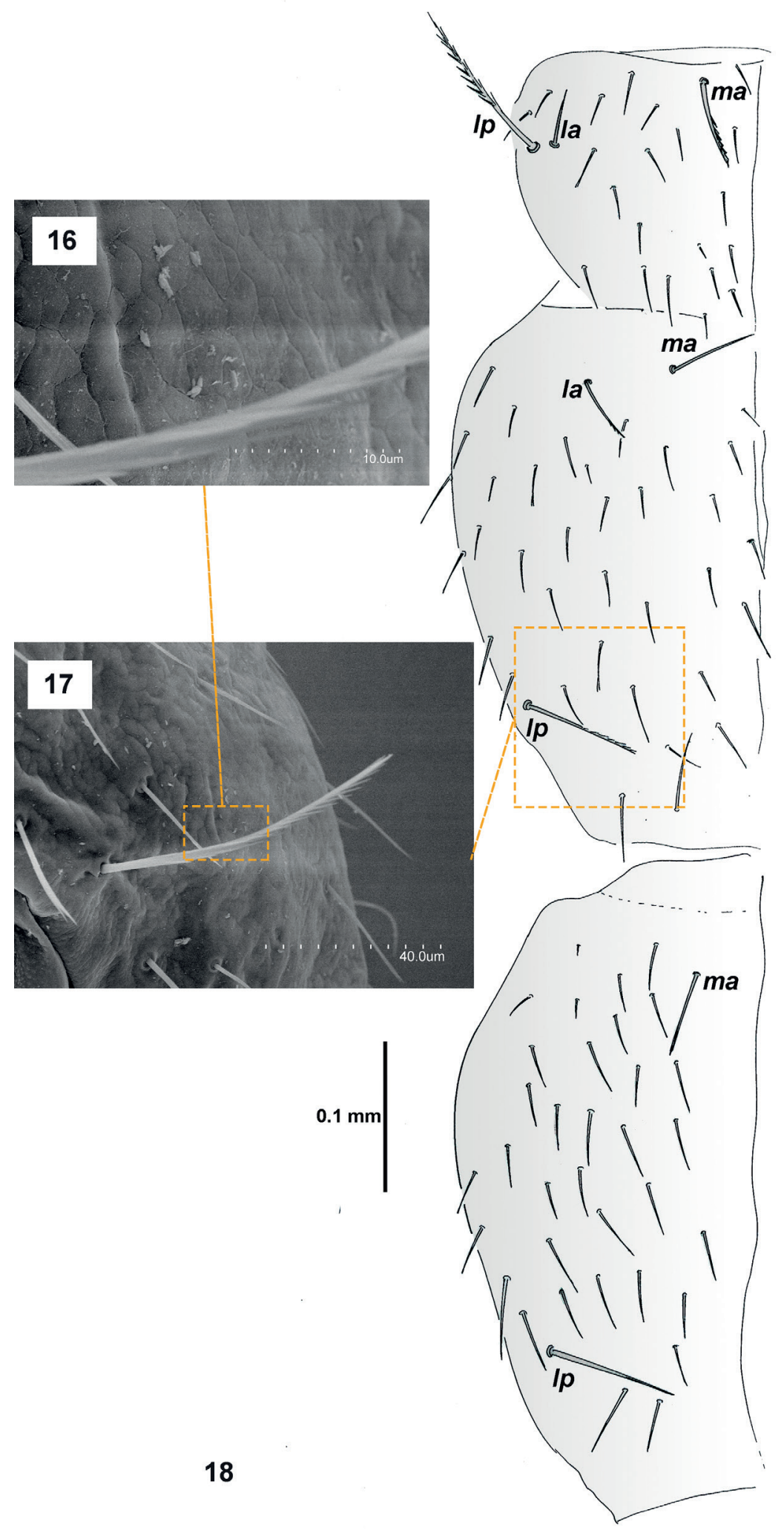

Figs 16-18. Kyrgyzstancampa sanare Sendra \& Ferreira gen. et sp. nov. 16. §, paratype (Coll. AS),

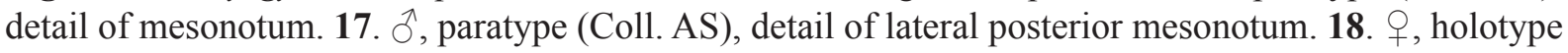
(IBB 92101), thoracic nota. 
has spread among them. Hence, one can see, especially in the entrance, small platforms and mattresses (Fig. 5). Visitors mostly use the entrance area, but stairs have also been installed deep inside the cave (Fig. 6), in which some mattresses were observed, indicating that the entire cave has been used for
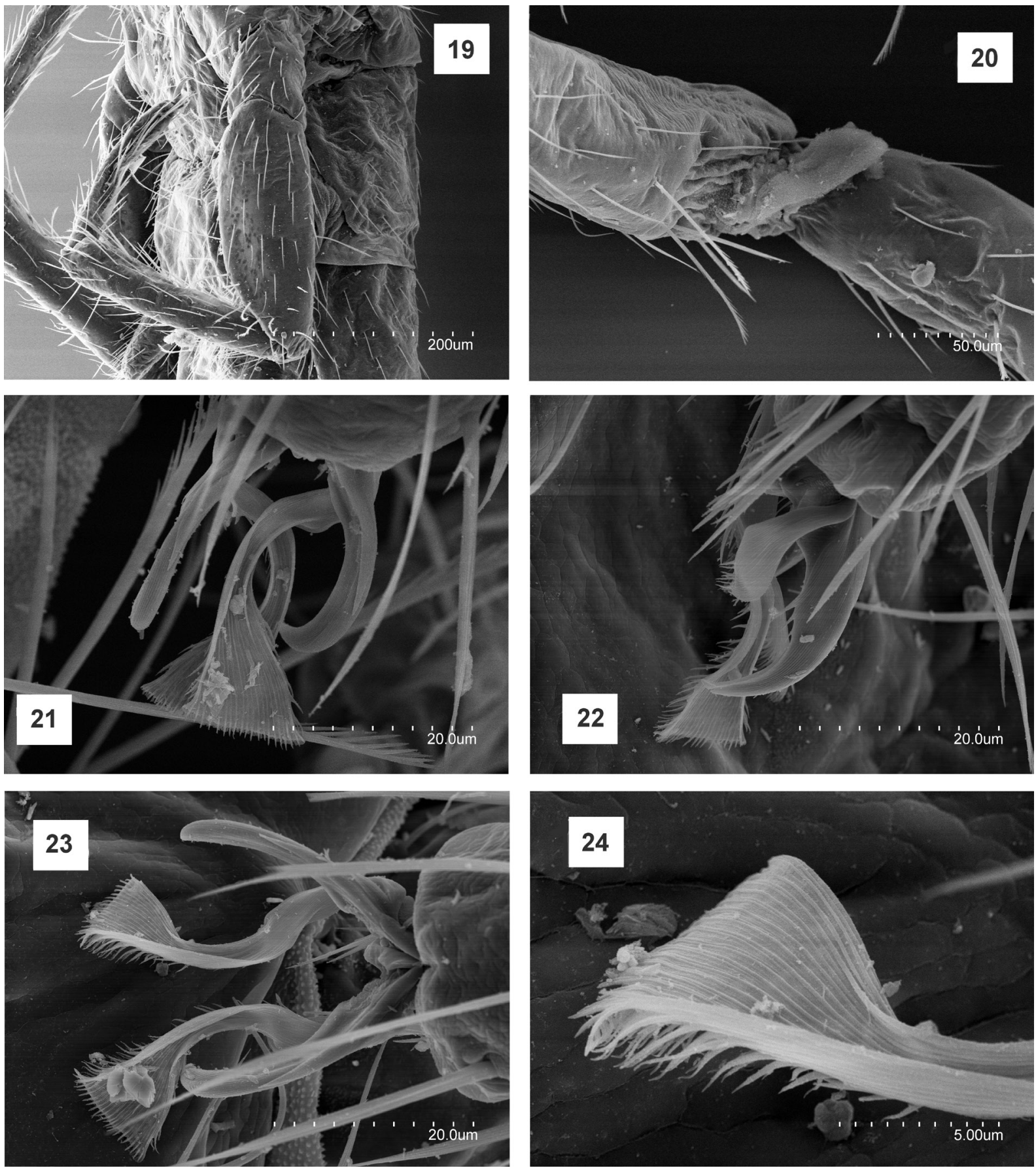

Figs 19-24. Kyrgyzstancampa sanare Sendra \& Ferreira gen. et sp. nov., §̂, paratype (Coll. AS). 19. Lateral view of end portion of metathorax and first and second abdominal segments with methatoracic legs. 20. Large, deep joint between femur and tibia with a longitudinal protrusion on the inner side in a metathoracic leg. 21. Lateral view of pretarsus in metathoracic leg. 22. Lateral view of pretarsus in metathoracic leg, here they observed the ventral spines on the claws. 23. Dorsal view of pretarsus in metathoracic leg. 24. Detail of lateral processes on pretarsus. 
therapeutic purposes. Specimens of Kyrgyzstancampa sanare Sendra \& Ferreira gen. et sp. nov. were only found in the last chamber of the cave, and always associated with old bat guano (Fig. 7). Several individuals were observed amidst the guano (Figs 8-9), rapidly escaping when disturbed. In these cases, they tended to enter the small spaces between the chitin fragments observed in the pile, so it was difficult to capture specimens without injuring them. The only organic resource observed inside the cave was bat guano from species of Rhinolophus Lacépède, 1799 (horseshoe bats) and a few organic materials left by visitors (such as cardboard pieces and wood). The cave is not well preserved as many accesses were built, thus deeply altering the pristine substrates. However, considering the lack of troglomorphic traits in the species (indicating that the cave is not its unique habitat) and given that apparently few visitors access the deeper parts of the cave, the species does not appear to be threatened.

\section{Phyletic affinities}

Kyrgyzstancampa Sendra \& Ferreira gen. nov. has similarities with several species of the paraphyletic genus Eutrichocampa Silvestri, 1902. In his diagnosis of Eutrichocampa, the tarsus ends abruptly instead of being acuminate towards the apex, which he considered to be a feature differentiating Eutrichocampa and Campodea (Silvestri 1902). For more than a century, several authors have been adding species to this genus, such as Wygodzinsky (1941, 1943), Condé (1947, 1994), Ionsecu (1955), Loksa (1960), García-Gómez (2016) and also Silvestri (1931a, 1932a, 1932b, 1933a), resulting in the current fifteen species of Eutrichocampa (Sendra et al. 2021). These species were described from localities scattered in the Americas, Africa, Asia, and Europe. In all of these contributions, the entire pretarsus shape is referred to as the differential character for Eutrichocampa: regularly curved claws with laminar or subcylindrical lateral processes with abundant barbs. Since Wygodzinsky (1941), Eutrichocampa has been considered a heterogeneous genus showing a wide variation in macrosetal patterns on the thorax and abdomen, including the presence or absence of dorsal macrosetae on the femora. In spite of the effort made by Condé (1956) to keep Eutrichocampa as a homogeneous taxon, several authors (including
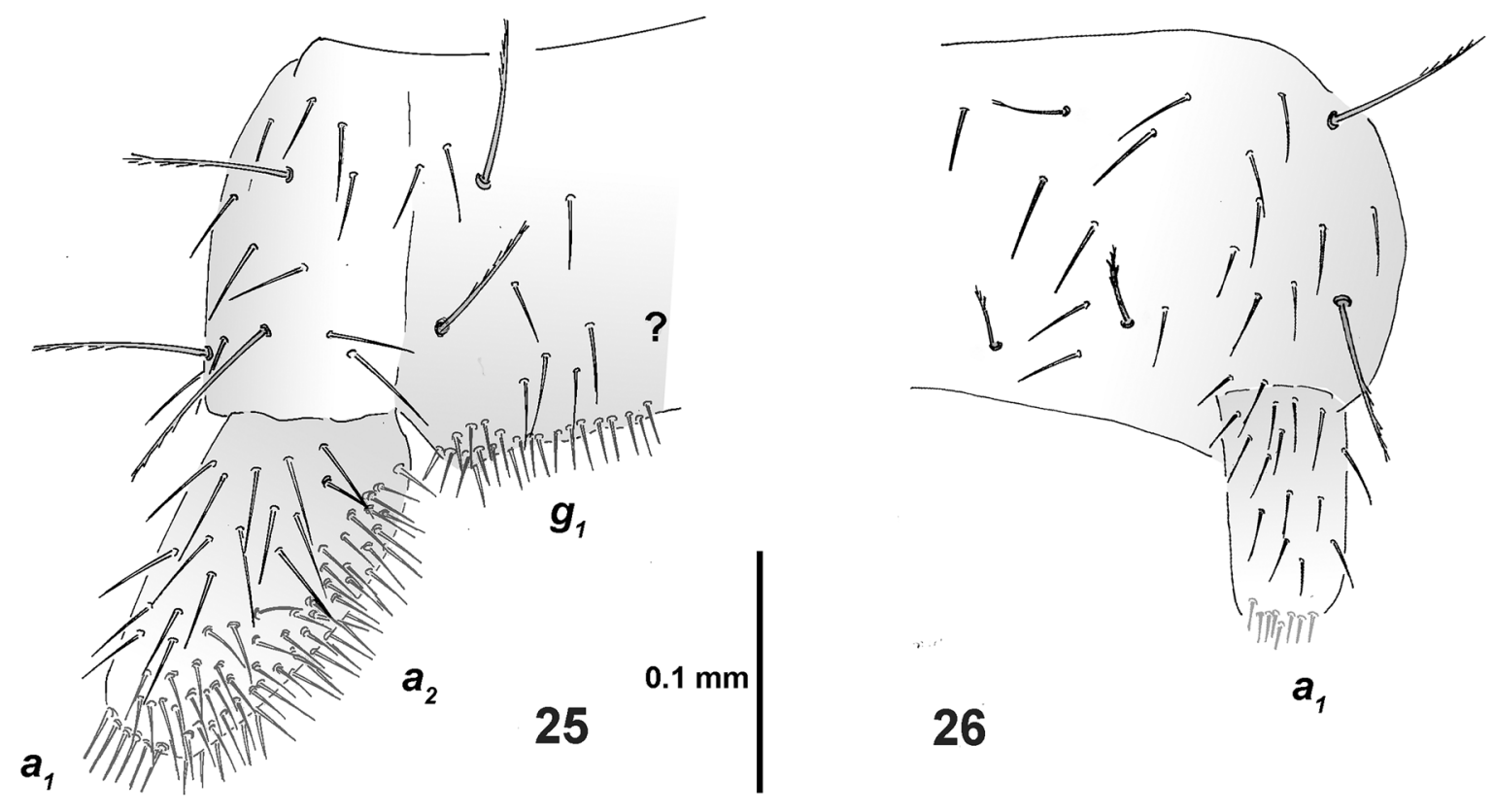

Figs 25-26. Kyrgyzstancampa sanare Sendra \& Ferreira gen. et sp. nov., urosternite I, lateral side. 25. $\widehat{\jmath}$, paratype (MZB (MCNB) 2021-2339). 26. ㅇ, paratype (MZB (MCNB) 2021-2338). Abbreviations: $a_{1}=$ glandular setae in distal portion of appendages; $a_{2}=$ lateral-ventral glandular setae; $g_{1}=$ posterior glandular setae of urosternite. 
Condé himself) have tried to arrange it into several genera and subgenera (Paclt 1957), proposing other genera with the same pretarsus trait and thoracic macrosetae of the Campodea pattern; for instance, Parallocampa Silvestri, 1933b with eleven species from North America, and Remycampa Condé, 1952, with two species from northwest Africa and the Canary Islands, and four monotypic genera: Allocampa Silvestri, 1931b from Cuba; Edriocampa Silvestri, 1933a from the South Aegean islands and Anatolian Peninsula; Libanocampa Condé, 1955 from Lebanon and Anatolia; and Pseudolibanocampa Xie \& Yang, 1991 from Guangdong and Yunnan in China. In 1957, Paclt proposed an artificial arrangement of Eutrichocampa by dividing it into four subgenera and the genus Leniwytsmania Paclt, 1957 for two species, both from China: L. orientalis (Silvestri, 1931a) and L. helvetica (Wygodzinsky, 1941). Our proposal of Kyrgyzstancampa Sendra \& Ferreira gen. nov. is another effort to unravel the diversity within the subfamily Campodeinae, in which this new genus can be included.

Several characters define Kyrgyzstancampa Sendra \& Ferreira gen. nov., such as the pretarsus with a regularly curved claw with tiny ventral and lateral microspines; the laminar lateral processes, striated on the dorsal side with short barbs on the ventral side (Figs 21-24); a unique femur-tibia joint; the macroseta pattern on the nota: $3+3 m a$, la, $l p$ macrosetae on the pronotum and metanotum, $2+2 m a, l p$ on the metanotum plus one dorsal femoral macroseta; and $1+1 l a$ and $2+2 l p$ on urotergites IV-VIII. Other notable features are the sparse clothing setae on the body, the plain paddle-shaped sensilla on the cupuliform organ, and the secondary sexual characters on the first urosternite. This combination of characters delineates Kyrgyzstancampa Sendra \& Ferreira gen. nov. from other genera of Campodeinae and all species of Eutrichocampa. The closest species to K. sanare Sendra \& Ferreira gen. et sp. nov. seems to be Eutrichocampa birabei Wygodzinsky, 1943, described from San Antonio de Arredondo, Córdoba in Argentina. Both share the shape of the pretarsus, the distribution of macrosetae on the nota and urotergites, and a dorsal macroseta on the femora. However, K. sanare Sendra \& Ferreira gen. et sp. nov. and E. birabei differ in the number of urotergal macrosetae and in the secondary sexual characters of the first urosternite. Furthermore, reuniting both species in Kyrgyzstancampa Sendra \& Ferreira gen. nov. would be a far-fetched approach, and new material on the South American species will be necessary to provide a more accurate description.

Subfamily Plusiocampinae Paclt, 1957

Genus Turkmenocampa Sendra \& Stoev, 2017

Turkmenocampa edaphica Sendra \& Sánchez-García sp. nov. urn:1sid:zoobank.org:act:6B28F41D-4B21-4E3C-A9B6-23FA7F8B0E17

Figs 27-31

\section{Etymology}

The specific epithet refers to the habitat of the new species.

\section{Type material}

\section{Holotype}

KYRGYZSTAN • +; "holotype- 907 MZB (MCNB) 2021-2340"; Jalal-Abad Region, Suzak Province, Kara Alma; 41 ${ }^{\circ} 15^{\prime} 59^{\prime \prime}$ N, 7322'43" E; alt. 1661 m; 16 Jul. 2019; A. Sendra leg.; endogean habitat near tree roots; MZB (MCNB) 2021-2340.

\section{Paratypes}

KYRGYZSTAN • 1 ô, mounted in Marc André II solution; "paratype- $ð 01$ MZB (MCNB) 2021-2341"; same collection data as for holotype; MZB (MCNB) 2021-2341 • 1 đ, mounted in Marc André II 
solution; "paratype- ${ }^{\top} 02$ Coll. AS"; same collection data as for preceding; Coll. AS $\bullet 1$ q, mounted in Marc André II solution; "paratype- 05 Coll. AS"; same collection data as for preceding; Coll. AS - 1 \%, mounted in Marc André II solution; "paratype- 08 "; same collection data as for preceding; Coll. AS • 1 + , mounted in Marc André II solution; "paratype- 09 Coll. AS"; same collection data as for preceding; Coll. AS • 1 क , mounted in Marc André II solution; "paratype-q 10 MZB (MCNB) 2021-2342 paratype"; same collection data as for preceding; MZB (MCNB) 2021-2342 • 1 ; ; " $\bigcirc 01$-paratype MCB (MCNB) 2021-2343"; Osh Province, Nookat District, Abshir Say River; 4008'50" N, 72 21'52" E; alt. 1851 m; 21 Jul. 2019; A. Sendra leg.; endogean habitat near Cupressus tree; MCB (MCNB) 20212343 • 1 क; "paratype- 92 MZB (MCNB) 2021-2344"; same collection data as for preceding; MZB (MCNB) 2021-2344 • 1 क; "paratype- 03 Coll AS"; same collection data as for preceding; Coll AS - 1 क; "paratype- 04 "; same collection data as for preceding; Coll. AS • 1 juv.; "paratype-J01 Coll AS"; same collection data as for preceding; Coll AS • 1 juv.; "paratype-J02 Coll AS"; same collection data as for preceding; Coll AS.

\section{Other material}

KYRGYZSTAN - 2 specs, mounted on an aluminium stage and coated with palladium-gold; same collection data as for holotype; Coll. AS.

\section{Description}

BoDy. Length 3.0 and $3.1 \mathrm{~mm}$ in two males, $3.5-4.8 \mathrm{~mm}$ in nine females, 2.2 and $2.3 \mathrm{~mm}$ in two juveniles (Table 1). Epicuticle smooth under optical microscope but slightly reticulated at high magnifications with irregular polygonal structures of variable size. Body with short to middle-sized smooth clothing setae.

HEAD. Antennae with 25-30 antennomeres in 10 complete intact antennae; antennae $0.6-0.8 \times$ length of body in adults and $0.9 \times$ in juveniles (Table 1). Medial antennomeres $1.4 \times$ as long as wide, apical antennomere $2.3 \times$ as long as wide. Cupuliform organ with about ten oviform sensilla of types I and II and an unknown number of tree-shaped sensilla (type III) in this olfactory complex (Fig. 27). Distal and central antennomeres with five whorls of barbed macrosetae and scattered smooth setae, plus single distal whorl of about ten short, thin gouge sensilla 15-18 $\mu \mathrm{m}$ long (Fig. 28). Proximal antennomeres with typical trichobothria, plus small and slightly shallow, $7 \mu \mathrm{m}$ long sensillum on $3^{\text {rd }}$ antennomere in ventral position.
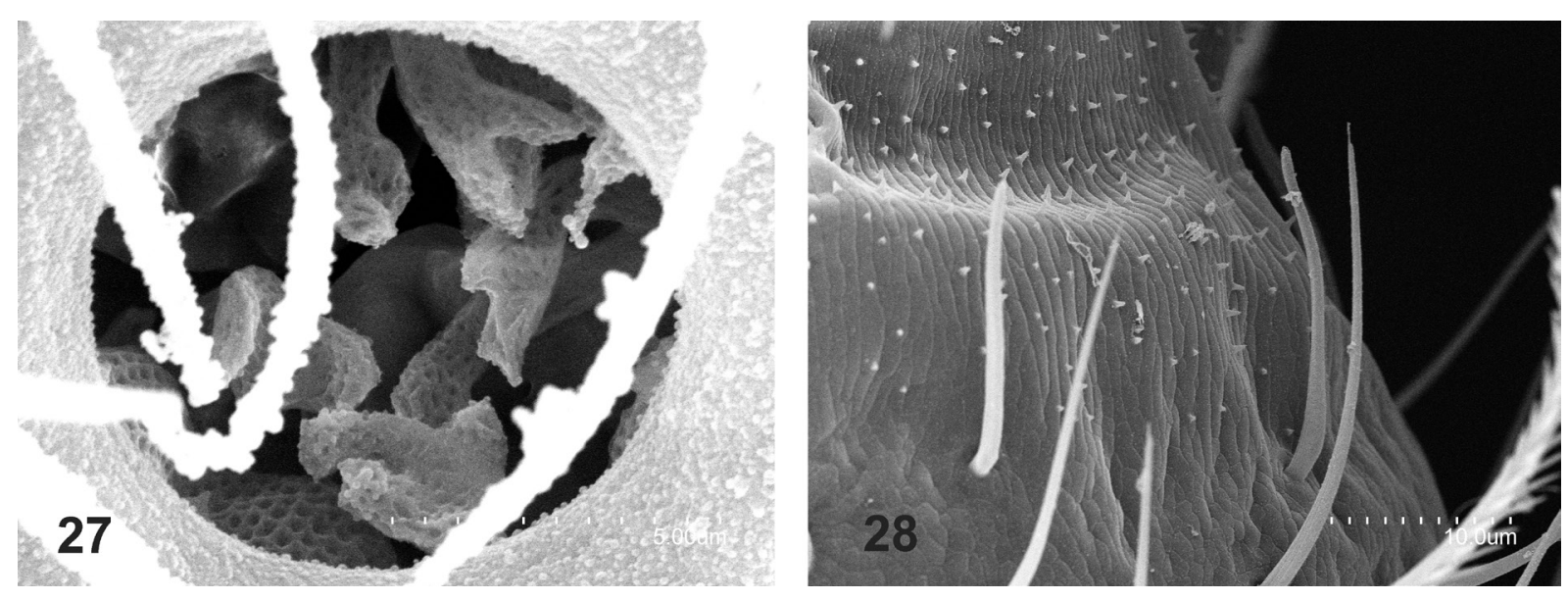

Figs 27-28. Turkmenocampa edaphica Sendra \& Sánchez-García sp., đ, paratype (Coll. AS). 27. Cupuliform organ in the last antennomere. 28. Medial antennomere with gouge sensilla. 
Plain frontal process with one frontal and two posterior macrosetae with length ratios a/p 45/30; three macrosetae along each side of insertion line of antennomere and setae $\mathrm{x}$ with thin distal barbs; length ratios $\mathrm{a} / \mathrm{i} / \mathrm{p} / \mathrm{x}$ 28/38/27/30 in paratype $q 05$ IBB-92102. Occiput of the head dorsally with $6+6$ macrosetae, including $3+3 l a, l p$ and $m p$ macrosetae, longer than clothing setae and with few distal barbs. Large suboval labial palps each with microsensillae on the surface, small shallow latero-external sensillum, two guard setae, and up to ten clothing setae in anterior position, with up to 120 neuroglandular setae in medial and posterior positions, in holotype.

THORAX. Thoracic macroseta distribution: pronotum and mesonotum with $1+1 \mathrm{ma}, 1+1 \mathrm{la}, 2+2 \mathrm{lp}$ macrosetae; metanotum with $1+1 \mathrm{ma}, 2+2 \mathrm{lp}$ macrosetae. All macrosetae long and slightly thickened, with barbs along distal five-fourths of each seta; marginal setae up to twice as long as and thicker than clothing setae, well barbed near base (Fig. 29). Metathoracic legs reaching abdominal segment VI, about $0.3-0.4 \times$ as long as body length (Table 1 ). Femora II-III each with one long, thick dorsal macroseta with barbs along distal half and with two long ventral macrosetae. Calcars with long barbs along one side. Tibiae I-III with two short, thick ventral macrosetae with barbs along distal two-thirds. Two rows of ventral barbed setae. Three smooth, dorsal distal tarsal setae longer than rest. Subequal claws with

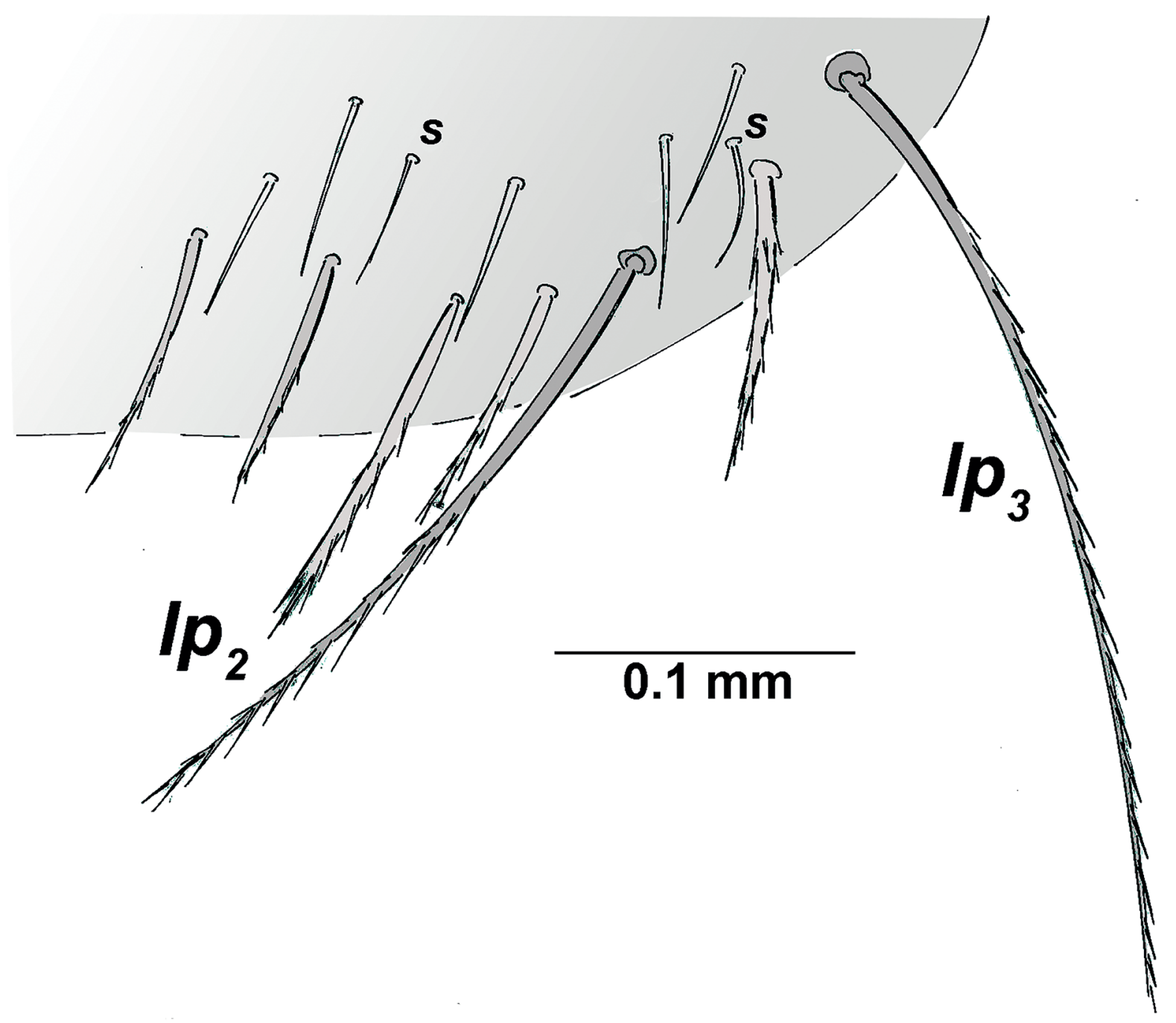

Fig. 29. Turkmenocampa edaphica Sendra \& Sánchez-García sp. nov., + , holotype (MZB (MCNB) 2021-2340), lateral posterior view of mesonotum. 
Table 1. Turkmenocampa edaphica Sendra \& Sánchez-García sp. nov., length of body, antennae, metathoracic legs, and cerci (measured in $\mathrm{mm}$ ); and number of antennomeres, cercal articles, and number of glandular $a_{1}$ setae on the first urosternite appendages.

\begin{tabular}{|c|c|c|c|c|c|c|c|}
\hline \multirow[t]{2}{*}{ Specimen } & \multirow{2}{*}{$\begin{array}{l}\text { Body } \\
\text { length }\end{array}$} & \multicolumn{2}{|c|}{ Antennae } & \multirow{2}{*}{$\begin{array}{c}\text { Metathoracic } \\
\text { legs }\end{array}$} & \multicolumn{2}{|c|}{ Cerci } & \multirow{2}{*}{$\begin{array}{c}\text { Glandular } \\
a_{1} \text { setae }\end{array}$} \\
\hline & & Length & $\begin{array}{c}\text { No. of } \\
\text { antennomeres }\end{array}$ & & Length & $\begin{array}{l}\text { No. of } \\
\text { articles }\end{array}$ & \\
\hline J02-paratype (Coll. AS) & 2.2 & 2.0 & 30 & 1.0 & - & - & 17 \\
\hline J01-paratype (Coll. AS) & 2.3 & 2.0 & 29 & 1.1 & - & - & 18 \\
\hline ¿01-paratype (MZB (MCNB) 2021-2341) & 3.0 & 2.0 & 26 & 1.1 & - & - & 22 \\
\hline đ02-paratype (Coll. AS) & 3.1 & 1.8 & 25 & 1.0 & 1.9 & $5(\mathrm{~b} 3)$ & 19 \\
\hline †10-paratype (Coll. AS) & 3.3 & 2.3 & 26 & 1.2 & - & - & 38 \\
\hline q03-paratype (Coll. AS) & 3.8 & - & - & 1.2 & - & - & 39 \\
\hline †08-paratype (Coll. AS) & 4.0 & 2.9 & 26 & 1.7 & - & - & 47 \\
\hline q01-paratype (MZB (MCNB) 2021-2343) & 4.2 & 3.4 & 30 & 1.5 & - & - & 32 \\
\hline †07-holotype (Coll. AS) & 4.3 & 3.0 & 26 & 1.6 & - & - & 58 \\
\hline q04-paratype (Coll. AS) & 4.4 & - & - & 1.5 & 3.8 & 7 (b3) & 45 \\
\hline †02-paratype (MZB (MCNB 2021-2344) & 4.5 & 2.8 & 29 & 1.5 & - & - & 38 \\
\hline †05-paratype (Coll. AS) & 4.8 & 3.0 & 25 & 1.9 & 3.1 & 7 (b3) & 49 \\
\hline q09-paratype (Coll. AS) & 4.8 & 3.4 & 26 & 1.9 & - & - & 64 \\
\hline
\end{tabular}

large basal half with tiny dorsal spines and distal half curved and thinner. Laminar processes of pretarsus smooth on dorsal side and with long, thin, ending curved and with enlarged on ventral side.

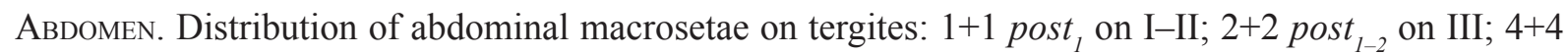
post $_{1-4}$ on IV-VII; $5+5$ post $_{1-5}$ on VIII; and 7+7 post $_{1-7}$ on abdominal segment IX. All tergal abdominal macrosetae long, thick and short, with thin barbs along the distal fourth-fifths.

Urosternite I with $8+8$ macrosetae (Figs 30-31); urosternites II-VII with 4+4 macrosetae; urosternite VIII with 1+1 macrosetae; urosternal macrosetae of medium length or longer, with long barbs in single row along distal one-fourth to three-fourths. Stylus with apical seta, subapical seta and ventromedial seta with few long barbs arranged in one row along distal half to four-fifths. Cerci $0.6-0.85 \times$ length of body, with 5 and 7 primary articles, not counting multi-divided basal article (Table 1). Each primary article covered with unarranged whorls of barbed macrosetae and typical whorl of short setae with tiny distal barbs.

Secondary sex characters. Female first urosternite with slightly thickened cylindrical appendages, each bearing microsensillae and 32-64 glandular $a_{1}$ setae in a distal field (Table 1; Fig. 31). Male first urosternite with short subcylindrical appendages, each bearing microsensillae and 19-22 glandular $a_{1}$ setae in distal field (Table 1; Fig. 30).

\section{Type locality}

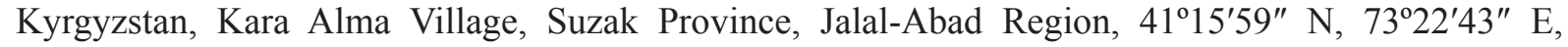
$1661 \mathrm{~m}$ a.s.1.

\section{Habitat}

The morphological features and locations where Turkmenocampa edaphica Sendra \& Sánchez-García sp. nov. has been found are congruent with those of a soil-dwelling species. In all cases, the species 
has been found in endogean habitats: under stones or among tree roots, always in humid places at $1661 \mathrm{~m}$ a.s.l. and $1851 \mathrm{~m}$ a.s.1., which is an average elevation for this mountainous country.

\section{Phyletic affinities}

Turkmenocampa edaphica Sendra \& Sánchez-García sp. nov. is the second known species of a genus known previously from a troglobitic species inhabiting Kaptarhana Cave in Eastern Turkmenistan, Turkmenocampa mirabilis Sendra \& Pavel, 2017, which is characterized by a Plusiocampinae pattern of macrosetae on the thorax and abdomen. Turkmenocampa also has a unique pretarsus consisting of subequal claws comprised of a large basal half with tiny dorsal spines, a thin, curved distal half and lateral laminar processes with long ventral barbs. Turkmenocampa mirabilis shows slight troglobiomorphic features: 30-32 antennomeres; up to twenty oviform sensilla on the cupuliform organ; gouge sensilla 18-26 $\mu \mathrm{m}$ long; middle antennomeres $2-2.5 \times$ as long as wide; legs slightly elongated; metathoracic legs reaching abdominal segment VIII; and much longer than wide appendages of the first urosternite, both in males and females (Sendra et al. 2017). However, T. edaphica Sendra \& Sánchez-García sp. nov. shows body characters of a soil dweller: 25-30 antennomeres; up to ten oviform sensilla on the cupuliform organ; middle antennomeres $1.4 \times$ as long as wide; gouge sensilla $15-18 \mu \mathrm{m}$ long; metathoracic legs reaching abdominal segment VI; and much longer than wide appendages of the first urosternite in both females and males. Turkmenocampa edaphica Sendra \& Sánchez-García sp. nov. differs from T. mirabilis by the greater thickness of barbed marginal setae and by the greater number of glandular $a_{1}$ setae on the first urosternite appendages in females: with 32-64 in T. edaphica Sendra \& SánchezGarcía sp. nov., 12-21 in T. mirabilis.

\section{Discussion}

\section{Updated knowledge of the Campodeidae fauna of Central Asia}

The lack of knowledge in Central Asia about Diplura, including its most diverse family, Campodeidae, even in the limitrophe regions, is quite striking (Sendra et al. 2017, 2020). Only three species were previously known: Campodea (Campodea) fragilis and C. (Dicampa) sprovierii are soil-dwellers and Turkmenocampa mirabilis is a cave dweller. The present contribution adds three more species, two of which are soil-dwelling species: C. (D.) catalana and T. edaphica Sendra \& Sánchez-García sp. nov.,

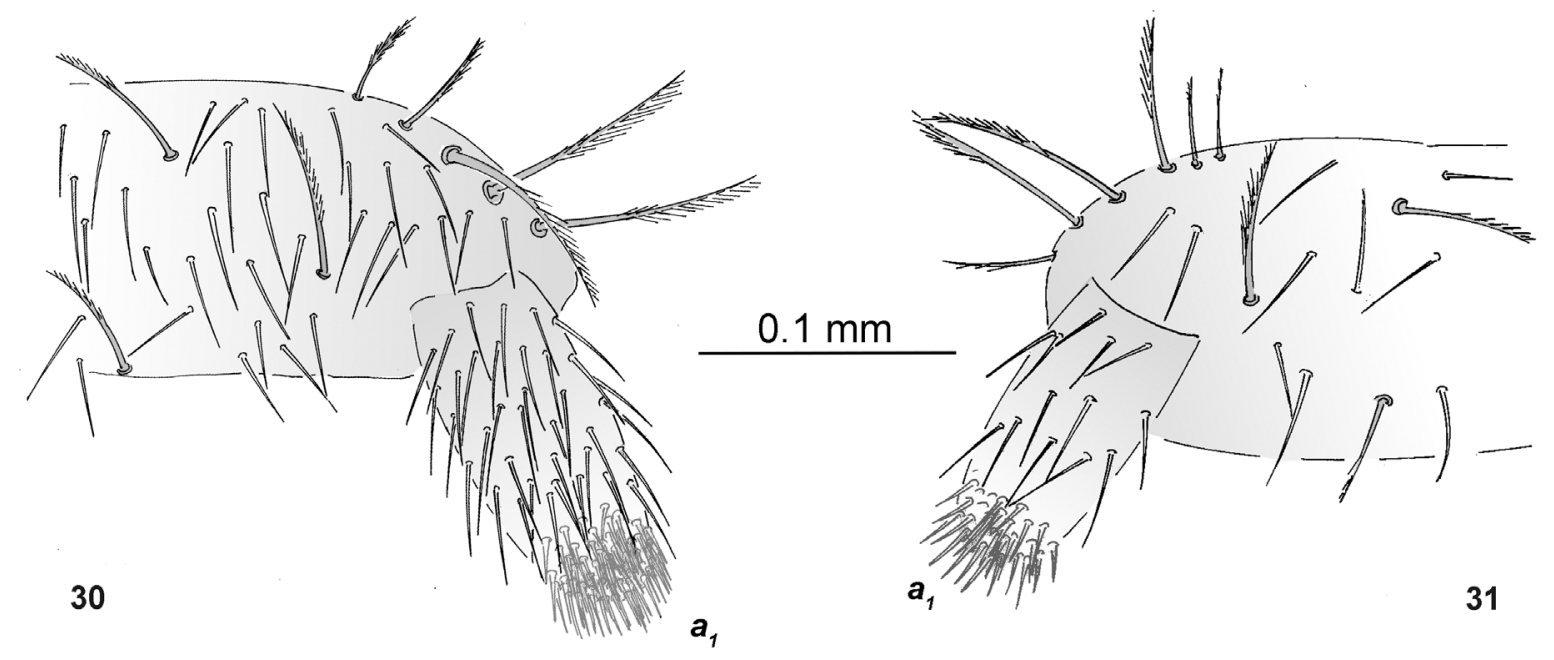

Figs 30-31. Turkmenocampa edaphica Sendra \& Sánchez-García sp. nov., urosternite I, lateral side. 30. ${ }^{\top}$, paratype (MZB (MCNB) 2021-2341). 31. , holotype (MZB (MCNB) 2021-2340). Abbreviation: $a_{1}=$ glandular setae in distal portion of appendages. 
and one non-troglomorphic species inhabiting a cave habitat: Kyrgyzstacampa sanare Sendra \& Ferreira gen. et sp. nov. The low density of caves in an area, sometimes located in very dry areas, usually results in a poor cave fauna which includes diplurans (Sendra et al. 2017). Knowledge of soil diplurans is very poor due to little sampling effort in both edaphic and cave ecosystems. Only three references, including this paper, have been published from Central Asia and nearby areas, compared to more than a thousand references worldwide (Sendra et al. 2021). In addition, cave research in Kyrgyzstan is scarce, especially when considering biospeleological assessments. Most of the subterranean arthropod species known to Kyrgyzstan are interstitial stygophiles/stygobionts (Turbanov et al. 2016a), only a few terrestrial cave species have been recorded (Turbanov et al. 2016b) and no Diplura have been mentioned in previous studies on the cave fauna of Kyrgyzstan. Hence, the soil and subterranean biodiversity of Kyrgyzstan can certainly be considered underestimated. Moreover, Kyrgyzstan has no specific laws on the protection of subterranean habitats. Therefore, various human activities (e.g., agriculture, mining, urbanization) may occur in karst areas, which threaten caves and associated fauna. Central Asia remains a poorly explored region from a zoological point of view, especially for some groups such as the diplurans.

\section{Acknowledgments}

We sincerely thank the patience of the entire Spanish expedition team: David Tinaut Ruano, Fernando Tinaut Ruano, Francisca del Carmen Ruano Díaz, José Alberto Tinaut Ranera, Pablo Barranco Vega, Pedro Oromí Masoliver, Rodrigo Barranco Campos and Sergio Montagud Alario with special thanks to our guides Mariya Chernyavskaya, Vasilyi Filipenko, Vladimir Levshunov and the unforgettable Islam as the most skilful driver. We also thank the electron microscopy team of the Central Service for Experimental Research (SCSIE) of the Universitat de València (Spain) for helping with SEM photography. We thank Dr Marconi Souza Silva (Centre of Studies on Subterranean Biology - CEBS/ UFLA), and our friends from Kyrgyzstan, Mrs Maria V. Chernyavskaya, Mr Asek A. Abdykulov, and Mr Daniyar Kh. Imlakov, for their kind help in the fieldwork. We are also grateful to the institutions that supported the study with funding for scholarships and infrastructure (FAPEMIG and VALE). R.L. Ferreira is grateful to the $\mathrm{CNPq}$ (National Council for Scientific and Technological Development) for the grant provided (CNPq n. 308334/2018-3). A. Sánchez-García is funded by an APOSTD2019 Research Fellowship from the Generalitat Valenciana and the European Social Fund (ESF).

\section{References}

Azadbakhsh S. \& Nozari J. 2016. First faunistic study of Diplura in north of Iran with records of two species of Campodea (Campodeidae). Entomologica Fennica 27: 53-56.

https://doi.org/10.33338/ef.59123

Beloglazova V.N. \& Smirnova N.B. (eds) 1987. Atlas of the Kirghiz USSR. Vol. 1. Natural Conditions and Resources. USSR State Board for Geodesy \& Cartography, Moscow. [In Russian]

Börner C. 1904. Zur Systematik der Hexapoden. Zoologischer Anzeiger 27: 511-533.

Condé B. 1947. Eutrichocampa remyi n. sp. (Diploures Campodéidés). Bulletin de la Société des Sciences de Nancy (nouvelle série) 6 (1): 60-62.

Condé B. 1952. Contribution à la faune endogée du Sahara. Diplopodes Pénicillates, Protoures, Diploures Campodéidés. Bulletin de la Société zoologique de France 76 (5-6): 349-365.

Condé B. 1955. Mission Henri Coiffait au Liban (1951). 4. Protoures et Diploures Campodéidés. Biospeologica 75: 397-412.

Condé B. 1956. Matériaux pour une monographie des Diploures Campodéidés. Mémoires du Muséum National d'Histoire naturelle Série A. Zoologie 12: 1-202. 
Condé B. 1994. Nouveaux Campodéidés endogés de Thaïlande. Revue suisse de la Zoologie 101 (2): 335-359. https://doi.org/10.5962/bhl.part.82493

Denis J.R. 1930. Sur la faune française des Aptérygotes, XI note: Diploures avec tableau de détermination des espèces françaises. Bulletin de la Société zoologique de France 55: 19-41.

Dudashvili S.D. \& Mikhailyov V.N. 1990. In the Labyrinths of the Heavenly Mountains. 'Kyrghyzstan'. Frunze. [In Russian]

García-Gómez A. 2016. Descripción de una nueva especie de Eutrichocampa (Idiocampa) (Diplura: Campodeidae) de Durango y Zacatecas, México. Revista Mexicana de Biodiversidad 87: 376-379. https://doi.org/10.1016/j.rmb.2016.05.003

Gvozdetskij N.A. 1981. Karst. 'Mysl', Moscow. [In Russian] Ionescu M.A. 1955. Diplura. In: Academiei (ed.) Fauna Republicii Populare Române, Insecta 7 (2): 48. Loksa I. 1960. Faunistisch-Systematische und Ökologische Untersuchungen in der Lóczy-Höhle bei Balatonfüred (Biospeologica Hungarica XL). Annales Universitatis Scientiarum Budapestinensis, Sectio Biologica 3: 253-266.

Lubbock J. 1873. Monograph of the Collembola and Thysanura. Ray Society, London. https://doi.org/10.5962/bhl.title.11583

Mamatkulov M.M. 1978. Some morphometric indicators of the caves of Central Asia. In: Peshchery (Caves) 17: 34-37. Geographical Society of the U.S.S.R., Perm. [In Russian]

Meinert F. 1865. Campodea: en familie af Thysanurernes orden. Naturhistorisk Tidsskrift 3: 400-440.

Paclt J. 1957. Diplura. In: Wytsman P. (ed.) Genera Insectorum. Fascicle 212. Mercurius, Antwerpen.

Sendra A., Sket B. \& Stoev P. 2017. A striking new genus and species of troglobitic Campodeidae (Diplura) from Central Asia. Subterranean Biology 23:47-68. https://doi.org/10.3897/subtbiol.23.14631

Sendra A., Palero F., Jiménez-Valverde A. \& Reboleira A.S.P.S. 2020. Diplura in caves: diversity, ecology, evolution and biogeography. Zoological Journal of the Linnean Society 192 (3): 675-689. https://doi.org/10.1093/zoolinnean/zlaa116

Sendra A., Jiménez-Valverde A., Selfa J. \& Reboleira A.S.P.S. 2021. Diversity, ecology, distribution and biogeography of Diplura. Insect Conservation and Diversity 14 (4): 415-425.

https://doi.org/10.1111/icad.12480

Silvestri F. 1902. Materiali per lo studio dei Tisanuri. Bollettino della Società entomologica italiana 33: 204-249.

Silvestri F. 1931a. Campodeidae (Insecta Thysanura) dell'estremo Oriente. Bolletino del Laboratorio d'Entomologia agraria in Portici 25: 286-320.

Silvestri F. 1931b. Campodeidae (Insecta, Thysanura) di Cuba. Bolletino del Laboratorio di Zoologia generale e agraria della R. Scuola superiore d'Agricoltura in Portici 24: 299-318.

Silvestri F. 1932a. Campodeidae (Thysanura) de España (primera parte). Eos 8: 115-164.

Silvestri F. 1932b. Campodeidae (Insecta, Thysanura) dell'Unione dell'Africa Meridionale. Bolletino del Laboratorio di Zoologia generale e agraria in Portici 26: 54-86.

Silvestri F. 1933a. Nuovi contributi alla conoscenza della fauna delle isole italiane dell'Egeo. Bolletino del Laboratorio di Zoologia generale e agraria in Portici 27: 61-111. 
Silvestri F. 1933b. Quarto contributo alla conoscenza dei Campodeidae (Thysanura) del Nord America. Bolletino del Laboratorio di Zoologia generale e agraria della R. Scuola superiore d'Agricoltura in Portici 27: 156-204.

Sultanov Z.S. 1972. Underground karst forms in Southern Fergana and their origin. In: Peshchery (Caves) 12-13: 88-95. Geographical Society of the U.S.S.R., Perm. [In Russian]

Turbanov I.S., Palatov D.M. \& Golovatch S.I. 2016a. The state of the art of biospeleology in Russia and other countries of the former Soviet Union: a review of the cave (endogean) invertebrate fauna. 1. Introduction - Crustacea. Entomological Review 96 (7): 926-963.

https://doi.org/10.1134/S0013873816070162

Turbanov I.S., Palatov D.M. \& Golovatch S.I. 2016b. The state of the art of biospeleology in Russia and other countries of the former Soviet Union: a review of the cave (endogean) invertebrate fauna. 2. Arachnida - acknowledgments. Entomological Review 96 (9): 1297-1333.

https://doi.org/10.1134/S0013873816090116

Westwood J.O. 1842. Description of a new genus of apterous hexapod insects found near London. The Annals and Magazine of Natural History 10: 231-234.

https://doi.org/10.1111/j.1365-2311.1842.tb03276.x

Wygodzinsky P. 1941. Beiträge zur Kenntnis der Dipluren und Thysanuren der Schweiz. Mémoires de la Société hélvetiques des Sciences naturelles 74 mémorie 2: 113-223.

Wygodzinsky P. 1943. Una nueva especie de Eutrichocampa Silvestri, 1901 (Campodeida, Diplura). Notas del Museo de La Plata 8 (Zoologia n ${ }^{\circ}$ 66): 141-145.

Xie R. \& Yang Y. 1991. Description of two new genera and three new species of Campodeidae in China (Diplura). Contributions from the Shanghai Institute of Entomology 10: 95-102.

Manuscript received: 15 May 2021

Manuscript accepted: 15 October 2021

Published on: 29 November 2021

Topic editor: Nesrine Akkari

Desk editor: Eva-Maria Levermann

Printed versions of all papers are also deposited in the libraries of the institutes that are members of the EJT consortium: Muséum national d'histoire naturelle, Paris, France; Meise Botanic Garden, Belgium; Royal Museum for Central Africa, Tervuren, Belgium; Royal Belgian Institute of Natural Sciences, Brussels, Belgium; Natural History Museum of Denmark, Copenhagen, Denmark; Naturalis Biodiversity Center, Leiden, the Netherlands; Museo Nacional de Ciencias Naturales-CSIC, Madrid, Spain; Real Jardín Botánico de Madrid CSIC, Spain; Zoological Research Museum Alexander Koenig, Bonn, Germany; National Museum, Prague, Czech Republic. 